RESEARCH ARTICLE

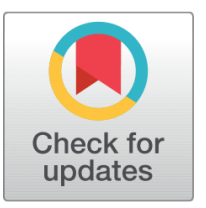

6 OPEN ACCESS

Received: $13-06-2020$

Accepted: $26-07-2020$

Published: 07-08-2020

Editor: Dr. Natarajan Gajendran

Citation: shams AE, Soliman AF, Ashour A, Marzouk AM, Elsharkawy SH (2020) Utilization of wood industrial wastes for production of chemicals and pharmaceuticals. Indian Journal of Science and Technology 13(28): 2892-2901. https://doi.org/ 10.17485/IJST/v13i28.917

* Corresponding author.

Tel: 0200101028921

ahmedadelashour@yahoo.com

Funding: None

Competing Interests: None

Copyright: ( $) 2020$ shams et al.. This is an open access article distributed under the terms of the Creative Commons Attribution License, which permits unrestricted use, distribution, and reproduction in any medium, provided the original author and source are credited.

Published By Indian Society for Education and Environment (iSee)

ISSN

Print: 0974-6846

Electronic: 0974-5645

\section{Utilization of wood industrial wastes for production of chemicals and pharmaceuticals}

\author{
Alaa E shams ${ }^{1}$, Amal F Soliman ${ }^{2}$, Ahmed Ashour ${ }^{2 *}$, Amani M Marzouk ${ }^{1,2}$, \\ Saleh H Elsharkawy ${ }^{2}$ \\ 1 Department of pharmacognosy, Faculty of pharmacy, Delta University for Science and \\ Technology, Gamasa City, Coastal international road, Egypt \\ 2 Department of Pharmacognosy, Faculty of Pharmacy, Mansoura University, Mansoura, \\ 35516, Egypt. Tel.: 0200101028921
}

\section{Abstract}

Objectives: This study aims to isolate and identify valuable chemicals and pharmaceuticals from the waste of wood (Pinus sylvestris L.) industry and to determine their biological value. Methods: Chromatographic technique was used to isolate compounds from the waste. The chemical identity of the isolated compounds were evidenced by different spectroscopic analyses as well as comparative studies of reported data. The microbial transformed product of pinosylvin mono methyl ether was quantitatively determined using fluorimetric method. All the isolated compounds were tested for their antitoxoplasmosis activity (in vitro) against Toxoplasma gondii. Findings/ Novelty: Nine compounds were isolated and identified including three diterpenes : (1 $\beta$-hydroxy dehydroabietic acid, 15-hydroxy dehydroabietic acid and Methyl-15-hydroxy dehydroabiet-18-ate) ; two aromatic aldehydes (coniferaldhyde and 3-hydroxy, 5-methoxy benzaldhyde); two stilbene derivatives; (Pinosylvin and Pinosylvin mono methyl ether); a flavan: (Pinocembrin) and a phytosterol ( $\beta$-sitosterol). For the first time, the fluorimetric method was used for quantitative determination of the novel metabolite produced, E-Pinosylvin mono methyl ether 5O- $\beta$-D-glucopyranoside, from the microbial biotransformation technique. All isolated compounds showed variable antitoxopasmosis activity, carried out for the first time, against $T$. gondii according to their $\%$ mortality and recorded $\mathrm{EC}_{50}$.

Keywords: Pinus sylvestris L.; saw dust; antitoxoplasmosis; fluorimetry; microbial transformation

\section{Introduction}

There are many wastes which could be subjected to more treatment for more benefit, The toxicity of waste printed circuit boards (PCBs) to bacteria was considered as the major limitation in bioleaching of copper from PCBs. To reduce the toxicity of PCBs, copper extraction from PCBs was investigated 
using bacteria-free cultural supernatant from some metallurgical microbial consortium ${ }^{(1)}$. Along with the rise of green chemistry, according to the biorefinery concept, lignocellulosic raw materials can be used for making valuable products that could replace petroleum derived products. The most important applications of lignocellulose biotechnology are in Bioenergy with the bioethanol and biohydrogen production and in Chemical Industry with some representative chemicals including acetone-butanol and polylactic acid (all obtained by glucose fermentation) ${ }^{(2)}$. There are many strategies that lead to high-value products from non-edible biomass waste streams also markedly increase the economic feasibility of lignocellulosic biorefineries ${ }^{(3)}$. Wood industrial wastes are also considered as a new source in the realm of nanocellulose ${ }^{(4) \mathrm{T}}$ he Genus Pinus (Pinaceae) comprises up to ninety species spread over the northern hemisphere ${ }^{(5)}$. The plants of this genus are used in rosin and turpentine industry ${ }^{(6)}$. Wastes of this genus can be exploited to produce valuable compounds, essential oils isolated by different techniques from Pinus pinaster showed antioxidant activity ${ }^{(7,8)}$ and also from other species ${ }^{(9,10)}$. Different species of genus Pinus showed anti-inflammatory, antitumor, antimicrobial, antioxidant and antiviral activities ${ }^{(11-14)}$. Pinus sylvestris $\mathrm{L}$. (Scot's pine tree) was mentioned in different scientific fields, It was also reported to contain a versatile array of secondary metabolites, including mono-, di-, sesqui- and triterpenes, flavonoids, stilbenes and lignans amongst other secondary metabolites ${ }^{(14)}$ and also in the effect of thermal modification process on the size distribution of dust particles of Scots pine generated during lengthwise milling ${ }^{(15)}$. The accumulation of the waste (saw dust) from the wood industries around Damietta governorate represents a serious hazards and environmental problem ${ }^{(16)}$. The biotechnology of industrial wastes for production of chemicals and pharmaceuticals has gained an interest recently to scientists ${ }^{(17)}$. The waste represents a valuable, priceless and renewable feed stock for production of useful products. Structure modification, through microbial transformation, of the major isolated compound was tried in this work in order to obtain more active or less toxic derivatives. Many compounds belonging to the same chemical classes of secondary metabolites previously identified in P. sylvestris showed antiprotozoal activity against Plasmodium falciparum, Trypanosoma brucei and Leishmania donovani ${ }^{(18,19)}$. Toxoplasmosis is a worldwide health problem that is caused by the intracellular parasite Toxoplasma gondii ${ }^{(20)}$. It is estimated that more than one billion people all over the world are infected with $T$. gondii ${ }^{(21)}$. The current anti T. gondii medication is not satisfactory. The first line therapy for the treatment or prophylaxis of toxoplasmosis is a combination of pyrimethamine and sulfadiazine, but unfortunately these drugs have serious side effects ${ }^{(22)}$. Herbal extracts as well as pure compounds of natural origin were shown to have anti toxoplasmosis activity in vivo and in vitro. Examples are the root extracts and fractions of Eurycoma longifolia Jack against virulent $\mathrm{RH}$ strain of $T$. gondii ${ }^{(23,24)}$; various molecular weight of chitosan nanoparticles ${ }^{(25)}$ as well as lipophilic fractions from Sorghum bicolor ${ }^{(26)}$. This report describes the isolation and identification of nine compounds from wood industry wastes of scot's pine, the production of E-Pinosylvin mono methyl ether 5-O- $\beta$-D glucopyranoside from pinosylvin mono methyl ether (first time). The biological activity of the isolated compounds and the microbial transformed metabolite, were tested against Toxoplasma gondii.

\section{Material and Methods}

\subsection{Plant material}

Saw dust (mesh size $30 \mathrm{~mm}$ ) was collected from the waste of companies of carpentry industry at Damietta governorate (Egypt) in May 2015. Samples were identified as Pinus sylvestris L. family, Pinaceae by Prof. Dr. Ibrahim Kherallah, Forestry and Wood Technology Department, Faculty of Agriculture (El-Shatby), Alexandria University, Egypt. A voucher specimen of the waste was deposited at Department of Pharmacognosy, Faculty of Pharmacy, Mansoura University.

\subsection{General}

Column chromatography (CC) was performed on silica gel 70-230 mesh (Merck, USA) and TLC on silica gel 60 $\mathrm{F}_{254}$ precoated plates $\left(0.25 \mathrm{~mm}\right.$, Merck, USA), silica gel column (Merck, USA). ${ }^{1} \mathrm{H}-,{ }^{13} \mathrm{C}-\mathrm{NMR}$ and $\mathrm{HMBC}$ spectra 
were determined on JEOL JNM-ECA500 (500 and $125 \mathrm{MHz}$ for ${ }^{1} \mathrm{H}$ - and ${ }^{13} \mathrm{C}$ - spectra, respectively) (JEOL, Japan) and Bruker DRX 600 (600 and $150 \mathrm{MHz}$ for ${ }^{1} \mathrm{H}$ - and ${ }^{13} \mathrm{C}$ - spectra, respectively) (Bruker, Germany). Components of $\alpha$-media ${ }^{(27)}$ used in microbial biotransformation. Biological assay, the virulent RH strain of Toxoplasma gondii was obtained from Laboratory of medical parasitology department, Faculty of Medicine, Alexandria University), maintained by intraperitoneal passages in albino mice ${ }^{(28)}$. Phosphate buffer saline (PBS), dimethyl sulfoxide (DMSO), trypan blue stain $(0.2 \% \mathrm{w} / \mathrm{v})$ and clindamycin was obtained from Advanz pharma, Egypt. Fluorimetric assay was performed on Shimadzu RF-1501 spectroflurometer (Shimadzu, Japan), spectroscopic methanol (Merck, USA)Solvents were reagent grade.

\subsection{Extraction and Isolation}

About $3 \mathrm{Kg}$ of P. sylvestris L. wood industrial waste was extracted with $\mathrm{MeOH}$ (3L x 6). The combined $\mathrm{MeOH}$ extract was evaporated under reduced pressure at $40^{\circ} \mathrm{C}$ to give $295 \mathrm{~g}$ of brown residue. The total residue was redissolved in $400 \mathrm{~mL}$ aqueous $\mathrm{MeOH}(50: 50 \mathrm{v} / \mathrm{v})$ and successively extracted with petroleum ether (1L x 3), $\mathrm{CH}_{2} \mathrm{Cl}_{2}$ $(1 \mathrm{~L} \times 3)$ and EtOAc (1 L x 2). Each of organic solvents extracts were evaporated under reduced pressure to obtain petroleum fraction A $(77.7 \mathrm{~g})$, fraction $\mathbf{B}(60.4 \mathrm{~g})$ and fraction $\mathbf{C}(1.0 \mathrm{~g})$, respectively.Each of fraction was separately chromatographed on silica gel columns according to the protocol in [ Figure 1] to obtain isolated compounds (1-9).

\subsection{Microbial biotransformation}

Microbial transformation of compound 5 was carried out adopting a two-stage fermentation protocol ${ }^{(29)}$. The fermentation was screened for potential metabolite using 22 microorganisms [ Table 1 ]. Only three microorganisms showed a single spot at $\mathrm{R}_{f}$ value 0.15 on TLC developed in $5 \% \mathrm{MeOH}$ in $\mathrm{CH}_{2} \mathrm{Cl}_{2}$-EtOAc (50:50, v/v), Asperigellus ochraceous NRRL 398, A. restricutus NRRL 2869 and Rhizopus sp. ATCC6060 and made visible by spraying with vanillin $/ \mathrm{H}_{2} \mathrm{SO}_{4}$ reagent followed by heating with a heating gun until maximum development of the spot colour. Preparative scale fermentation was performed utilizing A. ochraceous NRRL 398 due to ease purification of the product from secondary metabolites, using $200 \mathrm{mg}$ of compound 5 and incubated for 2 weeks. The culture broth was filtered and extracted with EtOAc $(0.5 \mathrm{~L} \mathrm{3})$, the combined extracts were evaporated to dryness to obtain $230 \mathrm{mg}$ of a yellow syrupy residue. The residue was chromatographed on silica gel column $(40 \mathrm{x} 0.8 \mathrm{~cm})$ and isocratically eluted with a mixture of $\mathrm{CH}_{2} \mathrm{Cl}_{2}$-EtOAc (50:50 v/v) containing 5\% of MeOH to yield $40 \mathrm{mg}$ of metabolite 10 as a yellow amorphous powder.

Table 1. Listof microorganisms used in biotransformation technique.

\begin{tabular}{ll}
\hline & Microorganisms \\
\hline Asperigellus alliaceous NRRL315 & Coriolus hirsutus ATCC MYA-828 \\
Asperigellus flavipes ATCC1013 & Coriolus versicolor ATCC48242 \\
Asperigellus flavus NRRL21882 & Cunnighamela blackselena NRRL1369 \\
Asperigellus niger NRRL 2995 & Cunnighamela elegans NRRL2310 \\
Asperigellus niger ATCC51049 & Cunnighamela elegans NRRL1395 \\
Asperigellus niger ATCC 51049 & Daedalea malicola NBRC 4978 \\
Asperigellus ochraceous NRRL 398 & Penicillium chrysogenium ATCC 9480 \\
Asperigellus restricutus NRRL2869 & Penicillium chrysogenium ATCC10002 \\
Asperigellus versicolor AUMC150201 & Rhodotorula rubra NRRL 41592 \\
Ceriporia spissa ATCC62024 & Rhizopus sp. ATCC 36060 \\
Cunnighamela blackselena MR198 & Rhizopogen sp. ATCC6060 \\
\hline
\end{tabular}

Metabolite 10: was obtained as a morphous yellow powder, $\mathrm{R}_{f} \quad 0.15, \mathrm{CH}_{2} \mathrm{Cl}_{2}-$ EtOAc (50:50, v/v) containing $5 \% \mathrm{MeOH} .{ }^{1} \mathrm{H}-{ }^{13} \mathrm{C}$ NMR and APT $\left(600,150 \mathrm{MHz}, \mathrm{DMSO}-\mathrm{d}_{6}\right.$ ) ( Table 2 ), HRESI-MS (positive ion mode) $\mathrm{m} / \mathrm{z}$ $411.1495[\mathrm{M}+\mathrm{Na}]^{+}$, integrated for the molecular formula is $\mathrm{C}_{21} \mathrm{H}_{24} \mathrm{O}_{7}$. Based on the previously reported data, it 


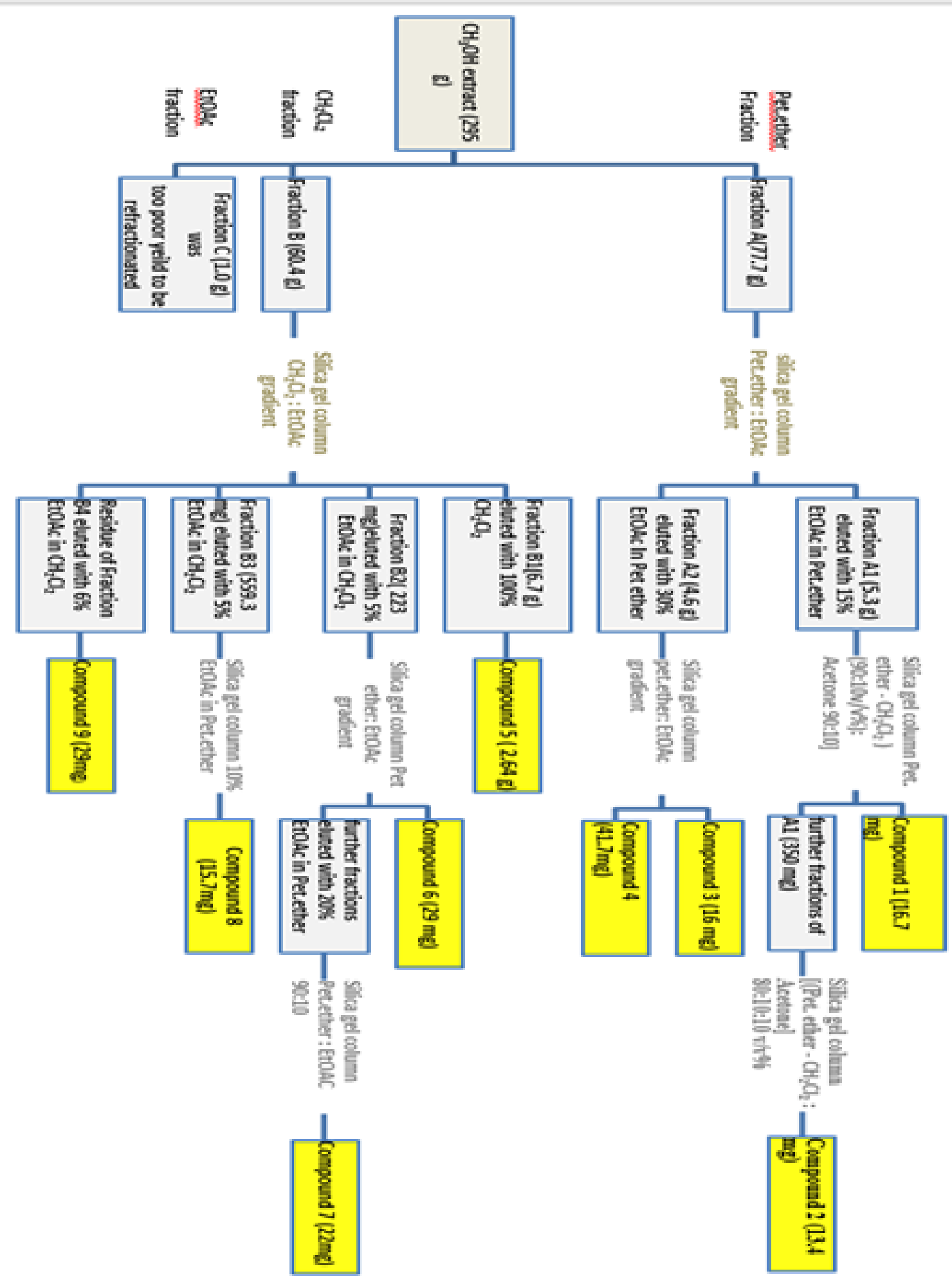

Fig 1. Protocol of isolation of compounds (1-9) from saw dust of P. sylvestris L. wood 
can be concluded that metabolite $\mathbf{1 0}$ is E-Pinosylvin mono methyl ether 5-O- $\beta$-D glucopyranoside.

Table 2. ${ }^{1} \mathrm{H}$ and ${ }^{13} \mathrm{C}$ data (600 and $\left.150 \mathrm{MHz}, \mathrm{DMSO}-\mathrm{d}_{6}\right)$ of metabolite (10) and the substrate (5)

\begin{tabular}{|c|c|c|c|c|c|}
\hline \multirow{2}{*}{ No. } & \multicolumn{3}{|c|}{ E-Pinosylvin mono methyl ether 5 -O- $\beta$-D glucopyranoside (10) } & \multicolumn{2}{|c|}{ E-Pinosylvin mono methyl ether (5) } \\
\hline & $1 \mathrm{H}$ & $13 \mathrm{C}$ & APT & $1 \mathrm{H}^{*}$ & $13 C^{*}$ \\
\hline 1 & 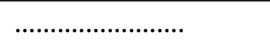 & 140.8 & $\mathrm{C}$ & .............................. & 138.8 \\
\hline 2 & $6.9 \mathrm{~s}$ & 108.1 & $\mathrm{CH}$ & $6.66 \mathrm{brs}$ & 106.2 \\
\hline 3 & $\ldots$ & 159.9 & $\mathrm{C}$ & 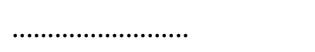 & 158.6 \\
\hline 4 & $6.63 \mathrm{~s}$ & 103.2 & $\mathrm{CH}$ & $6.29(1 \mathrm{H}, \mathrm{dd}, \mathrm{J}=2.4,2.4)$ & 100.9 \\
\hline 5 & 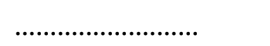 & 161.8 & $\mathrm{C}$ & 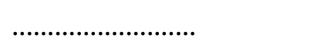 & 160.6 \\
\hline 6 & $6.8 \mathrm{~s}$ & 107.4 & $\mathrm{CH}$ & 6.61 brs & 102.9 \\
\hline A & $7.08(1 \mathrm{H}, \mathrm{d}, \mathrm{J}=16.5)$ & 128.9 & $\mathrm{CH}$ & $7.13(1 \mathrm{H}, \mathrm{d}, \mathrm{J}=16.5)$ & 128.3 \\
\hline$B$ & $7.15(1 \mathrm{H}, \mathrm{d}, \mathrm{J}=16.5)$ & 130.5 & $\mathrm{CH}$ & $7.17(1 \mathrm{H}, \mathrm{d}, \mathrm{J}=16.5)$ & 128.59 \\
\hline $1^{\prime}$ & ……............................ & 138.1 & $\mathrm{C}$ & $\ldots$ & 136.9 \\
\hline $2,66^{\prime}$ & $7.35(1 \mathrm{H}, \mathrm{t}, \mathrm{J}=7,7.5)$ & 127.36 & $\mathrm{CH}$ & $7.59(2 \mathrm{H}, \mathrm{d}, \mathrm{J}=8.4)$ & 126.4 \\
\hline $3,5^{\prime}$ & $7.50(1 \mathrm{H}, \mathrm{d}, \mathrm{J}=7.5)$ & 129.7 & $\mathrm{CH}$ & $7.37(2 \mathrm{H}, \mathrm{t}, \mathrm{J}=7.8,7.8)$ & 128.61 \\
\hline $4^{\prime}$ & $7.30(1 \mathrm{H}, \mathrm{d}, \mathrm{J}=7.5)$ & 128.8 & $\mathrm{CH}$ & $7.27(1 \mathrm{H}, \mathrm{t}, \mathrm{J}=7.2,7.2)$ & 127.5 \\
\hline $\mathrm{O}-\mathrm{CH} 3$ & 3.70 & 56.1 & $\mathrm{CH} 3$ & $3.75(3 \mathrm{H}, \mathrm{s})$ & 54.9 \\
\hline $\mathrm{OH}$ & ……............... & ............. & ................ & 9.4 & .............. \\
\hline $1 ”$ & $4.90(1 \mathrm{H}, \mathrm{d}, \mathrm{J}=7.2)$ & 102.0 & $\mathrm{CH}$ & $\ldots \ldots .$. & \\
\hline $2 ”$ & 3.34 & 74.5 & $\mathrm{CH}$ & .......... & \\
\hline $3 "$ & & 77.4 & $\mathrm{CH}$ & & \\
\hline $4 "$ & 3.60 to $3.70 \mathrm{~m}$ & 71.1 & $\mathrm{CH}$ & & \\
\hline $5 "$ & & 77.8 & $\mathrm{CH}$ & & \\
\hline $6 ”$ & 3.80 & 61.8 & $\mathrm{CH} 2$ & $\ldots \ldots \ldots \ldots$ & ….......... \\
\hline
\end{tabular}

\subsection{Fluorimetric assay}

\subsubsection{Fermentation and sampling procedures}

Quantitative determination of the produced metabolite was carried out using fluorimetric technique ${ }^{(30)}$. The substrate 5 was added separately to each of the stages, flasks containing one of the three microorganisms (Asperigellus ochraceous NRRL 398, A. restricutus NRRL 2869 and Rhizopus sp. ATCC6060 ) in presence of culture and substrate control, each of the culture broth was sampled daily $(1 \mathrm{ml})$, extracted with EtOAc / MeOH (9:1,v/v) for 14 days. All samples were air- dried, diluted to $10 \mathrm{~mL}$ in volumtric flasks with mixture of $\mathrm{MeOH}-\mathrm{H}_{2} \mathrm{O}(60: 40$, v/v) and Sampling was done in triplicate. The intensity values of fluorescence for each sample broth was calculated using standard curve ( Figure 3$)^{(30,31)}$. the unused concentration of substrate was determined fluorimetrically according to the reported procedure ${ }^{(32)}$. The fluorescence of each sample was recorded at $302.9 \mathrm{~nm}$ (excitation) and $402 \mathrm{~nm}$ (emission) at a scan speed of $2775 \mathrm{~nm} \mathrm{~min}^{-1}$. Spectra of both samples and standards were corrected for background according recommendations reported in ${ }^{(33)}$. Corrections were made using the software (Denovix) facilities of the instrument. The maximum concentration of the substrate at day zero was estimated as $200 \mathrm{ng} / \mathrm{ml}$. Concentration of the untransformed substrate was determined quantitatively by measuring intensity of its fluorescence. Concentration of the produced metabolite was indirectly calculated using the following formula:

Conc. of the product $=$ maximum conc. of the substrate $(200 \mathrm{ng} / \mathrm{ml})$ - conc. of untransformed substrate $(\mathrm{ng} / \mathrm{ml})$.

\subsubsection{Statistical analysis}

Calibration curves obtained from standard solutions in 9 points showed good linearity, and correlation coefficient was 0.985. All samplings were carried out in triplicate and experiments repeated at least 3 times. Data were expressed as mean + S.D statistically analyzed by using graph pad prism 6.0 (GraphPad Software, 2365 Northside Dr. Suite 560, 
San Diego, CA 92108) and Excel 2016.

\subsection{Anti toxoplasmosis assay}

This assay was carried out according to the described method ${ }^{(34)}$. Serial dilutions of $100 \mu \mathrm{g} / \mathrm{ml}$ to $3.125 \mu \mathrm{g} / \mathrm{ml}$ of each test compound were prepared in DMSO $(1 \% \mathrm{w} / \mathrm{v})$. Five $\mu \mathrm{l}$ of each dilution of test compounds were incubated with $45 \mu \mathrm{l}$ of tachyzoites suspension containing $10^{6}$ cells $/ \mathrm{ml}$ in a humidified $\mathrm{CO}_{2}$ chamber at $37^{\circ} \mathrm{c}$ for $24 \mathrm{~h}$. The mortality of tachyzoites was determined with trypan blue dye under light microscope and the results (mean value) were expressed as $\%$ mortality. Clindamycin was used as positive control.

\section{Results and Discussion}

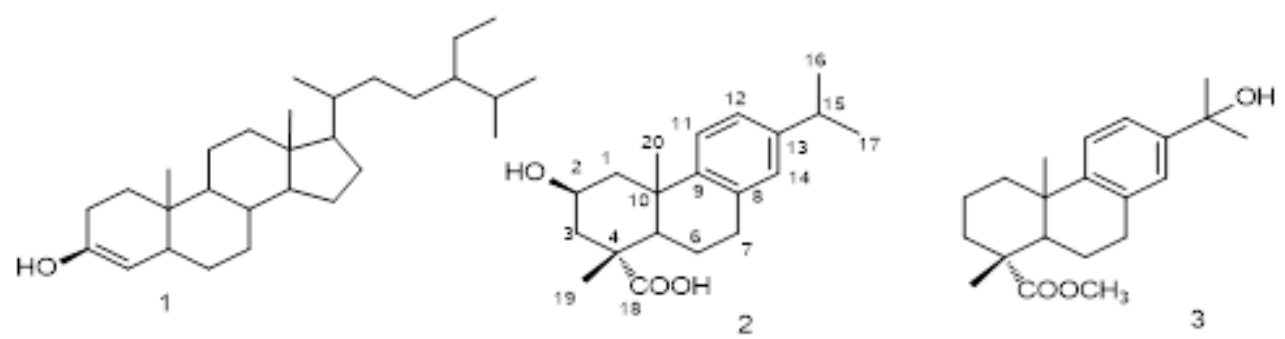<smiles>CC(C)(O)c1ccc2c(c1)CCC1C(C)(C(=O)O)CCCC21C</smiles>

4<smiles>COc1cc(/C=C/C=O)ccc1O</smiles>
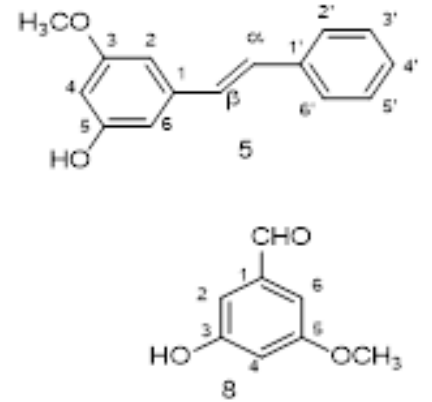<smiles>COc1cc(O)cc(O)c1C(=O)CC(OC)c1ccccc1</smiles>

6

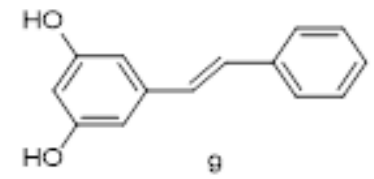

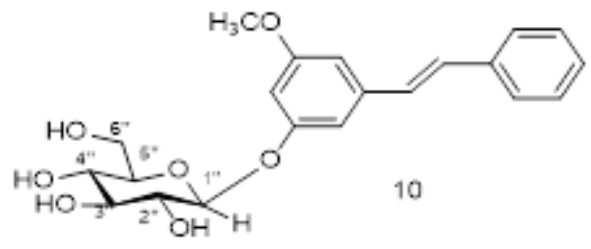

Fig 2. Chemical structures of compounds (1-9) and metabolite (10)

Nine compounds were isolated from the wood industry waste of P. sylvestris L. using different chromatographic techniques. The isolated compounds were identified using physical and spectroscopical data previously reportedas: $\beta$-sitosterol (1) ${ }^{(35)}$, three abietane diterpenes including $1 \beta$-hydroxy dehydroabietic acid 2, Methyl -15-hydroxy dehydroabiet-18-ate (3) and 15-hydroxy dehydroabietic acid (4) ${ }^{(36)}$; two stilbene derivatives, pinosylvin mono methyl ether (5) and pinosylvin (9) ${ }^{(37)}$; the flavan derivative, pinocembrin (6) ${ }^{(37)}$, coniferaldhyde (7) ${ }^{(38)}$ and 3hydroxy, 5-methoxy benzaldhyde (8) ${ }^{(39)}$ ( Figure 2 ). This is the first time to indicate the isolation of compounds (2) and (7) from this species. It is worth to mention the isolation of compound (8) for the first time from any natural 
source, as it was known as a synthetic compound used in organic synthesis ${ }^{(39)}$.

The major isolated compound $\mathbf{5}$ was screened for potential production of a new metabolite utilizing the biocatalytic activity of the selected 22 microorganisms including viz Asperigellus ochraceous NRRL 398, A. restricutus NRRL 2869 and Rhizopus sp ATCC 36060. Preparative scale fermentation was used for substantial preparation of the metabolite adapting the two- stage fermentation protocol utilizing A. ochraceous NRRL 398. The culture broth was extracted with EtOAc- $\mathrm{MeOH}(50: 50, \mathrm{v} / \mathrm{v})$. Concentrated residue $(230 \mathrm{mg})$ was loaded on a silica gel column, eluted with mixture of $\mathrm{CH}_{2} \mathrm{Cl}_{2}$-EtOAc (50:50) containing $5 \%$ of $\mathrm{MeOH}$. The isolated metabolite 10 was chemically identified as a new natural product, E-Pinosylvin mono methyl ether 5-O- $\beta$-D-glucopyranoside, using the chemical and spectroscopic techniques. HRESI-MS of a quasi molecular ion peak showed m/z $411.1495[\mathrm{M}+\mathrm{Na}]^{+}$, calculated value $\mathrm{m} / \mathrm{z} 411.1512$, corresponding to the molecular formula $\mathrm{C}_{21} \mathrm{H}_{24} \mathrm{O}_{7}$. The appearance of six new carbon signals in the aliphatic region of APT spectrum of metabolite $\mathbf{1 0}$ compared to that of the substrate $\mathbf{5}$ and the presence of a $\beta$-linked sugar was deduced from the large $\mathrm{J}$ value $(7.2 \mathrm{~Hz})$ of an anomeric proton doublet at $\mathrm{d} 4.90$ in the ${ }^{1} \mathrm{H}$ NMR spectrum of 10 which was correlated to an anomeric carbon signal at d102.0 in ${ }^{13} \mathrm{C}$-APT spectrum. The rest of signals in ${ }^{1} \mathrm{H}$ - and ${ }^{13} \mathrm{C}$ - APT spectra were comparable to those published for $\beta$-D-glucopyranose ${ }^{(40,41)}$.

The concentration of the biotransformation product 10 was determined indirectly (by difference) by measuring the concentration of the untransformed substrate in culture broth. This is because the substrate showed higher fluorescence intensity than the product, $\lambda_{\text {excitation }}$ and $\lambda_{\text {emission }}$ of the substrate 5 were determined at 302.9 and 402 $\mathrm{nm}$, respectively and the intensity of fluorescence was linear at concentrations range $(5-400 \mathrm{ng} / \mathrm{mL})$. The intensity of fluorescence (I) of the untransformed substrate in culture broth had been recorded as (Mean + S.D) for the three different microorganisms viz.; A. ochraceous NRRL 398, A. restricutus NRRL 2869 and Rhizopus sp. ATCC 36060 for 14 days. Concentrations of the untransformed substrate and the product were calculated by using the calibration curve of the substrate 5 ( Figure 3 ). According to these results, the decrease in the intensity of fluorescence of the substrate indicated its consumption in favor of the formation of the biotransformation product. Rhizopus sp. ATCC 36060 showed the highest yield followed by A. ochraceous NRRL398 and finally A. restricutus NRRL2869 at earlier time (day 7) ( Table 3 ). Although Rhizopus sp. had the best results in quantitative estimation of the yield (195 ng/mL), A. ochraceous was preferred and used in scaling up the microbial biotransformation because its yield was easier to isolate and purify of metabolite $\mathbf{1 0}$ from its culture broth.

Table 3. Concentrations $(\mathrm{ng} / \mathrm{ml})$ of the biotransformation product determined in culture broth of the three different fungi.

\begin{tabular}{|c|c|c|c|}
\hline Time (day) Fungi & A.ochraceous NRRL398 & A. restricutus NRRL 2869 & Rhizopus sp. ATCC36060 \\
\hline 1 & $0+0$ & $0+0$ & $0+0$ \\
\hline 2 & $36.37+21.4$ & $46.34+17.99$ & $74.27+11.13$ \\
\hline 3 & $82.75+22.5$ & $54.32+20.08$ & $103.61+33.86$ \\
\hline 4 & $118.17+19.04$ & $100.21+16.16$ & $150.58+11.10$ \\
\hline 5 & $125.65+17.1$ & $121.79+12.78$ & $170.04+3.49$ \\
\hline 6 & $134.62+15.1$ & $133.13+17.70$ & $192.48+0.50$ \\
\hline 7 & $140.61+5.5$ & $139.61+21.73$ & $195+0.13$ \\
\hline 8 & $155.57+6.83$ & $142.1+19.86$ & $195+0.13$ \\
\hline 9 & $156.07+0.87$ & $144.6+20.44$ & $195+0.13$ \\
\hline 10 & $156.0+0.87$ & $148.1+17.45$ & $195+0.13$ \\
\hline 11 & $156.0+0.87$ & $148.1+17.45$ & $195+0.13$ \\
\hline 12 & $156.0+0.87$ & $148.1+17.45$ & $195+0.13$ \\
\hline 13 & $156.0+0.87$ & $148.1+17.45$ & $195+0.13$ \\
\hline 14 & $156.0+0.87$ & $148.1+17.45$ & $195+0.13$ \\
\hline
\end{tabular}

All results arerepresented as mean + S.D

The experimental results indicated that the isolated compounds and the new microbial metabolite of wood industry wastes of $P$. sylvestris have in vitro antitoxoplasmosis activity against $T$. gondii Rh virulent strain. This strain 


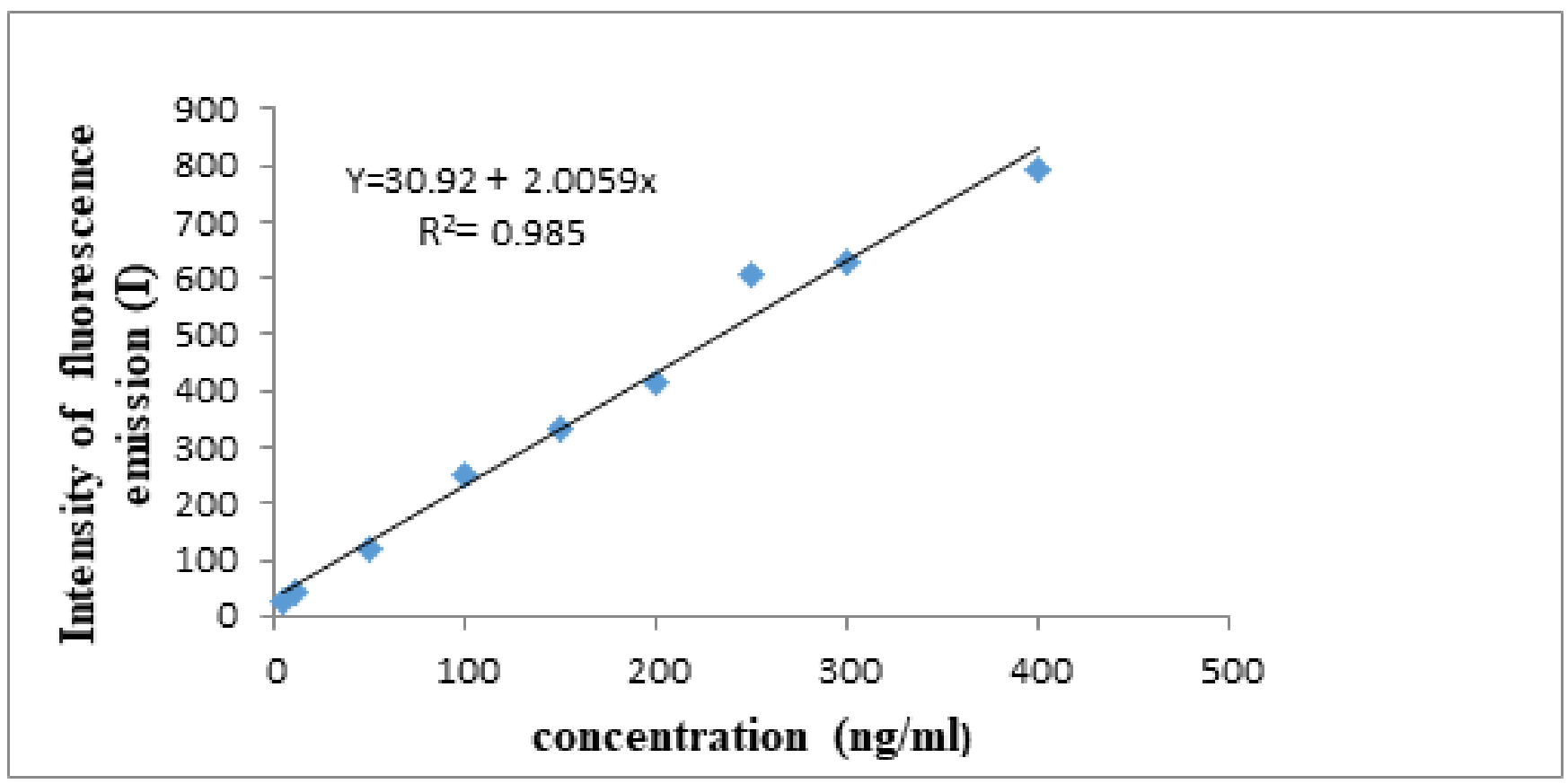

Fig 3. Calibration curve of E-pinosylvin mono methyl ether (5)

belongs to type I T. gondii, which is the most virulent and is usually associated with acute infections and congenital toxoplasmosis $^{(42)}$.

Compounds (2-10) were tested for their antitoxoplasmosis activity against tachyzoites of T. gondii ( Table 4). In vitro screening of these compounds revealed that all test compounds had considerable antitoxoplasmosis activity at concentrations of 100 and50 $\mu \mathrm{g} / \mathrm{mL}$ with \% mortality ranging from 85.6-50.2. Compounds 2,5 \& 10 showed the highest activity at both concentrations $(83.7,83.1 ; 85.6,84.4 ; 81.8,81.2)$ ( Table 4 ) which is slightly lower than that of clindamycin used as positive control in this assay $(90.3 \& 87.1) . \mathrm{EC}_{50}$ of the test compounds $\mathbf{2}, \mathbf{5} \& \mathbf{1 0}$ were comparable to that of clindamycin, with those of $\mathbf{2 , 5}$ even slightly lower ( Table 4).

Table 4. Results of in vitro screening of anti toxoplamosis activity (\% mortality)

\begin{tabular}{lllllllllll}
\hline \multirow{2}{*}{ Conc. $(\mu \mathrm{g} / \mathrm{ml})$} & \multicolumn{10}{c}{ \% Mortality } \\
\cline { 2 - 11 } & Clind. & 2 & 3 & 4 & 5 & 6 & 7 & 8 & 9 & 10 \\
\hline 100 & 90.3 & 83.7 & 52.5 & 66.6 & 85.6 & 56.0 & 60.0 & 58.4 & 62.7 & 81.8 \\
50 & 87.1 & 83.1 & 50.9 & 59.1 & 84.4 & 50.2 & 58.0 & 55.6 & 60.3 & 81.2 \\
25 & 84.5 & 81.4 & 39.2 & 42.2 & 81.5 & 45.9 & 52.2 & 48.2 & 51.8 & 80.0 \\
12.5 & 81.8 & 78.7 & 38.6 & 41.6 & 80.1 & 39.9 & 40.3 & 36.1 & 40.1 & 73.6 \\
6.25 & 75.2 & 72.5 & 30.5 & 34.1 & 73.6 & 31.0 & 37.0 & 32.4 & 36.2 & 71.0 \\
3.125 & 72.4 & 70.9 & 27.1 & 25.2 & 71.1 & 25.7 & 26.2 & 24.8 & 30.4 & 69.1 \\
$\mathrm{EC} 50(\mu \mathrm{g} / \mathrm{ml})$ & 1.008 & 0.9805 & 47.863 & 34.674 & 0.9462 & 47.863 & 21.878 & 30.200 & 22.38 & 1.12 \\
\hline
\end{tabular}

\section{Conclusion}

This study revealed that wood industry waste from $P$. sylvestris could be exploited for the production of valuable products showing variable anti toxoplasmosis activity in vitro for the first time. In addition to production of a new biotransformed metabolite, E-Pinosylvin mono methyl ether 5-O- $\beta$-D-glucopyranoside, that also showed high antitoxoplasmosis activity. The used material, P. sylvestris, showed to have the same chemical profile as that of the 
genus. Moreover, the Fluorimetric assay described in this work was very sensitive and selective for quantitative determination of the produced metabolite based on the intensity of the fluorescence.

\section{References}

1) Sadh PK, Duhan S, Duhan JS. Agro-industrial wastes and their utilization using solid state fermentation: a review. Bioresources and Bioprocessing. 2018;5(1). Available from: https://dx.doi.org/10.1186/s40643-017-0187-z.

2) Silva D, L L. Adding Value to Agro-Industrial Wastes. Industrial Chemistry. 2016;2:103-103. Available from: https://doi.org/10.4172/ 2469-9764.1000e103.

3) Elangovan S, Afanasenko A, Haupenthal J, Sun Z, Liu Y, Hirsch AKH, et al. From Wood to Tetrahydro-2-benzazepines in Three WasteFree Steps: Modular Synthesis of Biologically Active Lignin-Derived Scaffolds. ACS Central Science. 2019;5(10):1707-1716. Available from: https://dx.doi.org/10.1021/acscentsci.9b00781.

4) Rajinipriya M, Nagalakshmaiah M, Robert M, Elkoun S. Importance of Agricultural and Industrial Waste in the Field of Nanocellulose and Recent Industrial Developments of Wood Based Nanocellulose: A Review. ACS Sustainable Chemistry \& Engineering. 2018;6:28072828. Available from: https://dx.doi.org/10.1021/acssuschemeng.7b03437.

5) Keeley JE. Ecology and evolution of pine life histories. Annals of Forest Science. 2012;69(4):445-453. Available from: https://dx.doi.org/ 10.1007/s13595-012-0201-8.

6) Rogachev AD, Salakhutdinov NF. Chemical Composition ofPinus sibirica(Pinaceae). Chemistry \& Biodiversity. 2015;12:1-53. Available from: https://dx.doi.org/10.1002/cbdv.201300195.

7) Meullemiestre A, Kamal I, Maache-Rezzoug Z, Chemat F, Rezzoug SA. Antioxidant Activity and Total Phenolic Content of Oils Extracted from Pinus pinaster Sawdust Waste. Screening of Different Innovative Isolation Techniques. Waste and Biomass Valorization . 2014;5:283292. Available from: https://doi.org/10.1007/s12649-013-9237-8.

8) Meullemiestre A, Petitcolas E, Maache-Rezzoug Z, Ginies C, Chemat F, Rezzoug SA. Isolation of volatils from maritime pine sawdust waste by different processes: Ultrasound, microwave, turbohydrodistillation, and hydrodistillation. Wood Material Science \& Engineering. 2014;9(2):76-83. Available from: https://dx.doi.org/10.1080/17480272.2014.881915.

9) Karaoğul E, Alma MH. Solvent-free microwave and hydro-distillation extraction of essential oils from the sawdust of pines: Correlation with heat-map. BioResources2019;14(4). Available from: https://doi.org/10.15376/biores.14.4.8229-8240.

10) Salem MZM, Zeidler A, Böhm M, Mohamed MEA, Ali HM. GC/MS Analysis of Oil Extractives from Wood and Bark of Pinus sylvestris, Abies alba, Picea abies, and Larix decidua. BioResources. 2015;10(4). Available from: https://dx.doi.org/10.15376/biores.10.4.7725-7737.

11) Sakagami H, Ikeda M, Unten S, Takeda K, Murayama J, Hamada A, et al. Antitumor activity of polysaccharide fractions from pine cone extract of Pinus parviflora Sieb. et Zucc Anticancer research. 1987;7(6):1153-1159.

12) Himejima M, Hobson KR, Otsuka T, Wood DL, Kubo I. Antimicrobial terpenes from oleoresin of ponderosa pine treePinus ponderosa: A defense mechanism against microbial invasion. Journal of Chemical Ecology. 1992;18(10):1809-1818. Available from: https://dx.doi. org/10.1007/bf02751105.

13) Wei K, Sun Z, Yan Z, Tan Y, Zhu X, Wang X, et al. Effects of Taishan Pinus massoniana pollen polysaccharide on immune response of rabbit haemorrhagic disease tissue inactivated vaccine and on production performance of Rex rabbits. Vaccine. 2011;29(14):2530-2536. Available from: https://doi.org/10.1016/j.vaccine.2011.01.068.

14) Li B, Shen YH, He YR, Zhang WD. Chemical Constituents and Biological Activities of Pinus Species. Chemistry \& Biodiversity. 2013;10:2133-2160. Available from: https//doi.org/10.1002/cbdv.201100373.

15) Piernik M, Rogoziński T, Krauss A, Pinkowski G. The influence of the thermal modification of pine (Pinus sylvestris L.) wood on the creation of fine dust particles in plane milling: Fine dust creation in the plane milling of thermally modified pine wood. Journal of Occupational Health. 2019;61(6):481-488. Available from: https//doi.org/10.1002/1348-9585.12075.

16) Reinhold K, Traumann A, Tint P. Environmental and Occupational Impact on Human Health of Dust and Chemicals from Modern Technologies. Environmental Engineering and Management Journal. 2014;13(9):2233-2241. Available from: https://dx.doi.org/10.30638/ eemj.2014.249.

17) Tang WL, Zhao H. Industrial biotechnology: tools and applications. Biotechnology Journal: Healthcare Nutrition Technology. 2009;4(12):1725-1739. Available from: https://doi.org/10.1002/biot.200900127.

18) Kedzierski L, Curtis JM, Kaminska M, Jodynis-Liebert J, Murias M. In vitro antileishmanial activity of resveratrol and its hydroxylated analogues against Leishmania major promastigotes and amastigotes. Parasitology Research. 2007;102(1):91-97. Available from: https: //dx.doi.org/10.1007/s00436-007-0729-y.

19) Nour AMM, Khalid SA, Kaiser M, Brun R, Abdalla WE, Schmidt TJ. The antiprotozoal activity of methylated flavonoids from Ageratum conyzoides L. Journal of Ethnopharmacology. 2010;129(1):127-130. Available from: https://dx.doi.org/10.1016/j.jep.2010.02.015.

20) Montoya JG, Liesenfeld O. Toxoplasmosis. The Lancet. 2004;363(9425):1965-1976. Available from: https://dx.doi.org/10.1016/s01406736(04)16412-x.

21) HOFFMANN S, BATZ MB, MORRIS JG. Annual Cost of Illness and Quality-Adjusted Life Year Losses in the United States Due to 14 Foodborne Pathogenst. Journal of Food Protection. 2012;75(7):1292-1302. Available from: https://dx.doi.org/10.4315/0362-028x.jfp$11-417$. 
22) Ahmadpour E, Ebrahimzadeh MA, Sharif M, Edalatian S, Sarvi S, Montazeri M, et al. Anti-Toxoplasma Activities of Zea Mays and Eryngium Caucasicum Extracts, In Vitro and In Vivo. Journal of Pharmacopuncture. 2019;22(3):154-159. Available from: https://doi.org/10.3831/KPI.2019.22.020.

23) Kavitha N, Noordin R, Chan KL, Sasidharan S. In vitro Anti-Toxoplasma gondii Activity of Root Extract/Fractions of Eurycoma longifolia Jack. BMC Complementary and Alternative Medicine. 2012;12(1):91-98. Available from: https://dx.doi.org/10.1186/1472-6882-12-91.

24) Kavitha N, Noordin R, Chan KL, Sasidharan S. Cytotoxicity activity of root extract/fractions of Eurycoma longifolia Jack root against vero and Hs27cells. Journal of Medicinal Plants Research. 2010;4:2383-2387. Available from: https://doi.org/10.5897/JMPR10.568.

25) Teimouri A, Azami SJ, Keshavarz H, Esmaeili F, Alimi R, Mavi SA, et al. Anti-<em $>$ Toxoplasma $<$ /em $>$ activity of various molecular weights and concentrations of chitosan nanoparticles on tachyzoites of RH strain. International Journal of Nanomedicine. 2018; Volume 13:1341-1351. Available from: https://dx.doi.org/10.2147/ijn.s158736.

26) Abugri DA, Jaynes JM, Witola WH. Anti-Toxoplasma activity of Sorghum bicolor-derived lipophilic fractions. BMC Research Notes. 2019;12(1). Available from: https://dx.doi.org/10.1186/s13104-019-4732-z.

27) El-Sharkawy S. Microbial conversion of tamoxifen. Applied Microbiology and Biotechnology. 1991;35(4):436-439. Available from: https://dx.doi.org/10.1007/bf00169745.

28) El-Tantawy NL, Soliman AF, Abdel-Magied A, Ghorab D, Khalil AT, Naeem ZM, et al. Could Araucaria heterophylla resin extract be used as a new treatment for toxoplasmosis? Experimental Parasitology. 2018;195:44-53. Available from: https://dx.doi.org/10.1016/j. exppara.2018.10.003.

29) Soliman AF, Naeem ZM, Khalil AT, Shimizu K, El-Sharkawy SH. Microbial transformation of the labdane diterpene 13-epicupressic acid. World Journal of Pharmaceutical Science. 2018;6(5):61-69. Available from: http://www.wjpsonline.org/.

30) Felscher D, Wulfmeyer M. A New Specific Method to Detect Cyanide in Body Fluids, Especially Whole Blood, by Fluorimetry. Journal of Analytical Toxicology. 1998;22(5):363-366. Available from: https://dx.doi.org/10.1093/jat/22.5.363.

31) Kamtekar S, Keer V, Patil V. Estimation of phenolic content, flavonoid content, antioxidant and alpha amylase inhibitory activity of marketed polyherbal formulation. Journal of Applied Pharmaceutical Science. 2014;4(9):61-65. Available from: 10.7324/JAPS.2014.40911.

32) Papoti VT, Tsimidou MZ. Looking through the qualities of a fluorimetric assay for the total phenol content estimation in virgin olive oil, olive fruit or leaf polar extract. Food Chemistry. 2009;112(1):246-252. Available from: https://dx.doi.org/10.1016/j.foodchem.2008. 05.081 .

33) Guilbault G. Practical Fluorescence, Theory Methods and Techniques. and others, editor;New York. Marcel Dekker. 1973.

34) Cover B, Gutteridge WE. A primary screen for drugs to prevent transmission of Chagas's disease during blood transfusion. Transactions of the Royal Society of Tropical Medicine and Hygiene. 1982;76(5):633-635. Available from: https://dx.doi.org/10.1016/0035-9203(82) 90228-0.

35) Nyigo VA, Peter X, Mabiki F, Malebo HM, Mdegela RH, Fouche G. Isolation and identification of euphol and $\beta$-sitosterol from the dichloromethane extracts of Synadenium glaucescens. The Journal of Phytopharmacology. 2016;5(3):100-104.

36) Schultz TP, Boldin WD, Fisher TH, Nicholas DD, Mcmurtrey KD, Pobanz K. Structure-fungicidal properties of some 3- and 4hydroxylated stilbenes and bibenzyl analogues. Phytochemistry. 1992;31(11):3801-3806. Available from: https://dx.doi.org/10.1016/ s0031-9422(00)97531-9.

37) Napal GND, Defagó MT, Valladares GR, Palacios SM. Response of Epilachna paenulata to Two Flavonoids, Pinocembrin and Quercetin, in a Comparative Study. Journal of Chemical Ecology. 2010;36(8):898-904. Available from: https://dx.doi.org/10.1007/s10886-010-98231.

38) Panyo J, Matsunami K, Panichayupakaranant P. Bioassay-guided isolation and evaluation of antimicrobial compounds fromIxora megalophyllaagainst some oral pathogens. Pharmaceutical Biology. 2016;54(9):1522-1527. Available from: https://dx.doi.org/10.3109/ 13880209.2015.1107106.

39) Cano M, Ladlow M, Balasubramanian S. Practical Synthesis of a Dithiane-Protected 3', '`-Dialkoxybenzoin Photolabile Safety-Catch Linker for Solid-Phase Organic Synthesis. The Journal of Organic Chemistry. 2002;67(1):129-135. Available from: https://dx.doi.org/10. 1021/jo010703e.

40) Kim HK, Choi YH, Choi JS, Choi SU, Kim YS, Lee KR, et al. A new stilbene glucoside gallate from the roots of Polygonum multiflorum. Archives of Pharmacal Research. 2008;31(10). Available from: https://doi.org/10.1007/s12272-001-2100-7.

41) Kanchanapoom T, Suga K, Kasai R, Yamasaki K, Kamel MS, Mohamed MH. Stilbene and 2-Arylbenzofuran Glucosides from the Rhizomes of Schoenocaulon officinale. CHEMICAL \& PHARMACEUTICAL BULLETIN. 2002;50(6):863-865. Available from: https: //dx.doi.org/10.1248/cpb.50.863.

42) Lau YL, Lee WC, Gudimella R, Zhang G, Ching XT, Razali R, et al. Deciphering the Draft Genome of Toxoplasma gondii RH Strain. PLOS ONE. 2016;11(6):e0157901-e0157901. Available from: https://dx.doi.org/10.1371/journal.pone.0157901. 